\title{
OPEN Ecological and health risk assessment of trace metals in water collected from Haripur gas blowout area of Bangladesh
}

\author{
M. Farhad Howladar ${ }^{1 凶}$, Md. Numan Hossain ${ }^{1}$, Khaleda Akter Anju ${ }^{1}$ \& Debjani Das ${ }^{2}$
}

The study aims to assess the trace metals and physicochemical properties of water in the adjacent to the Sylhet gas blowout area. Trace metals were analyzed using atomic absorption spectrophotometer, whereas physicochemical parameters were evaluated in-situ state using portable instruments and also in the laboratory. Trace metals $\mathrm{Pb}, \mathrm{Cd}$, and $\mathrm{Ni}$ were found in the water samples higher than the acceptable limit by WHO standards, whereas the concentration of $\mathrm{Cu}$ and $\mathrm{Zn}$ were within acceptable limit, respectively. The correlation coefficient matrix and factor loading analysis spectacle that the interrelationship among the physicochemical parameters, trace elements, as well as other ions are moderate to strongly corellated which reflecting the homogeneous source of origin. According to contamination factor, Nemerow multi-factor index, pollution load index, and also, potential ecological risk index, the water of the region is quite polluted in case of $\mathrm{Pb}, \mathrm{Cd}$, and $\mathrm{Ni}$ but unpolluted for $\mathrm{Cu}$ and $\mathrm{Zn}$. The water quality index indicates that treatment of water is required before using it for domestic purposes. The health quotient and hazard index results are less than standard value 1 suggesting that there is no noncarcinogenic risk in the area. The carcinogenic analysis shows that the lifetime incremental cancer risk mean value of $\mathrm{Cd}$ and $\mathrm{Ni}$ are fairly insignificant and $\mathrm{Pb}$ is more significant for children to cause health problem. The ILCR value of Cd and Ni are insignificant whereas $\mathrm{Pb}$ is significant to pose health risk for adults. Physicochemical parameters revealed that the water was slightly acidic and soft in nature implying to avoid the water from this area for drinking purposes. At the end, it can be concluded that this study will be useful for the residence as well as the policymaker to take the protective surveillance measures around the areas.

Water is an important component of earth which is much essential for our daily life. Based on use, water can be typified as drinking, domestic, livestock, irrigation, industrial and so on. Currently, the quality of water is degrading visibly in different areas in Bangladesh as well as in the world. The anthropogenic activities such as rapid industrialization, irrigation, shipping, extracting mineral resources from the earth's ground and others are responsible for it. Among them industrial operations associated pollution are mostly palpable. However, it is well known that the blowout of gas is one of the severe accidents in petroleum industry causing the degradation of various environmental components such as soil, water, air, etc. Moreover, the uncontrolled underground releases of natural gas are a vital issue to increase methane concentration in groundwater, surface water, soil, and air in the atmosphere ${ }^{1}$.

Haripur gas field was discovered in Sylhet region by the Pakistan Petroleum Limited (PPL) ${ }^{2}$. The country's first drilling activities took place at Haripur (1955) in Sylhet where 6 wells were drilled by PPL. Among them, only two (Syl-3 and Syl-6) wells became operative ${ }^{2,3}$. During these drilling operations, the first detection of gas in the country took place in Haripur ${ }^{4}$. While conducting the operation, the blowout occurred in Syl-1 and Syl-4 well because of abnormal high pressure ${ }^{5}$. As a result, the gas has been blowing out forcefully, so damaged the total structures and environment of that area. Still, endlessly gas is seeping from this area from that time (Fig. 1). Thus, this study deemed that seeped methane changes the concentration level of trace elements with physicochemical properties of ground-surface water around the adjacent areas. Ultimately, this might have an impact on the public health and ecological system in the area. In addition, the natural gas leaks in freshwater aquifers

${ }^{1}$ Department of Petroleum and Mining Engineering, Shahjalal University of Science and Technology, Sylhet, Bangladesh. ${ }^{2}$ Department of Geography and Environment, Shahjalal University of Science and Technology, Sylhet, Bangladesh. ${ }^{\varpi}$ email: farhad-pme@sust.edu 

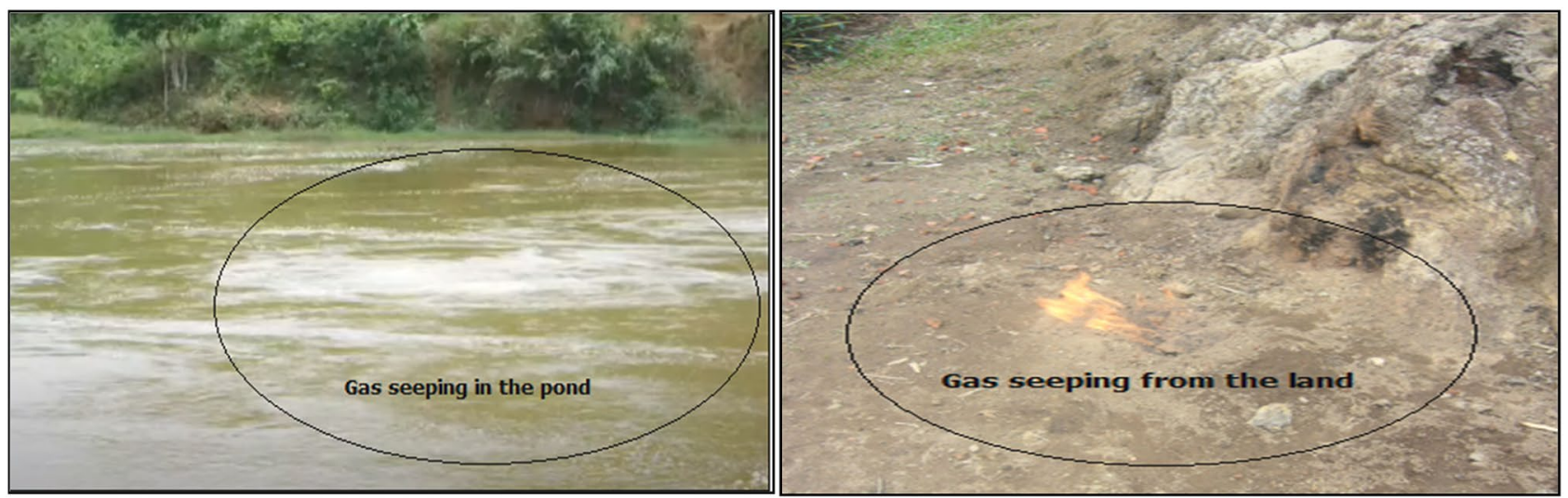

Figure 1. The seeping of natural gas by groundwater, surface water and the land in the area.

can affect groundwater quality by modifying redox conditions, increasing in $\mathrm{pH}$; declining in Eh; decreasing iron and manganese oxides and forming alkalinity by methane oxidation and many more ${ }^{1}$.

About 1.2 billion people are suffering from contaminated drinking and domestic use of water in the world ${ }^{6}$. Higher levels of pollutants in water are largely responsible for increasing threat toecology, human health, and the environment ${ }^{7}$. The health and the ecological system may have a considerable risk by transferring TMs in water to different plants to social health ${ }^{8,9}$.At present, trace elements effluence in water is the most concerned issue for the scientist as it crafts the serious health and ecological problems in nature ${ }^{10,11}$. Toxic metal-associated water pollution, health, ecological and environmental risk also mentioned by various authors ${ }^{12-16}$. The moderate to high ecological risk and heavy metal pollution was found in a lithofacies of subsurface well as well in the drilling crew and people in a hydrocarbon drilling environment ${ }^{17}$. Trace metals are the most common aquatic contaminants and responsible for creating a toxic environment ${ }^{18}$. TMs pollutions have turn into an attractive issue in the world because of its high diligence, toxic and carcinogenic characters ${ }^{19}$. The carcinogenic risks of heavy metal were found to have higher than the standard limit in several studies in Bangladesh which might have increase the cancer risk exposure to different ages of people ${ }^{20}$.Particularly, Nadim et al. ${ }^{21}$ and Wang et. al. ${ }^{22}$ entailed that environmental water pollution due to the operation of oil gas industries is very frequent in the developing country as well as in the Globe.

The Sylhet region has some previous studies on geology, structure, and blowout impact on environments are performed by Hiller and Elahi ${ }^{23}$, Khan et al. ${ }^{24}$, Faruque ${ }^{25}$, Khan and $\mathrm{Nasir}^{26}$. A number researchers like Howladar and Rahman ${ }^{27}$, Mamun et al. ${ }^{28}$, Numanbakth et al. ${ }^{29}$, Rahman et al. ${ }^{30}$ and others are carried out the research works to evaluate the impact of mining sector, gas field and rock crushing sides on ground-surface water chemistry including trace metals with another properties. However, no studies have been found on the impact of the blowout on the aquatic environment or the toxicity of TMs in surface and ground waters in the region. Thus, this study assessed (1) some physicochemical parameters and the trace metals ( $\mathrm{Ni}, \mathrm{Cd}, \mathrm{Cu}, \mathrm{Zn}$, and $\mathrm{Pb}$ ) that would have accumulated in the water body of the adjacent areas due to the blowout, (2) the ecological and human health risk coupled with TMs and the physicochemical properties of water, (3) the long-term impact of the massive gas blowout on humans and ecology, (4) the possible pollution intensity for effective management of water resources around the gas blowout areas of the Sylhet gas field. Finally, the present article on ecologicalhealth risk evaluation will be encouraging to the proper authority and policy maker for understanding the highly risky areas to look after the overall ecosystem and human health professionally.

\section{Materials and methods}

Outline of the study region. The study was conducted in and around the blow out zones of the Haripur gas fields of Jaintapur Upazila which lies between the geographical coordinates $24.58^{\prime} 36^{\prime \prime} \mathrm{N}^{\prime} \mathrm{N}$ to $24.58^{\prime} 57^{\prime} \mathrm{N}$ (latitudes) and $92.01^{\prime} 35^{\prime \prime} \mathrm{E} \mathrm{E}$ to $92.01^{\prime} 57^{\prime} \mathrm{E}$ (longitudes). The Upazila is divided into six administrative units and 70 villages. The total population of this area is about $1,21,458^{31}$. This area is bounded by Meghalaya in the north, Sylhet city, Kanaighat-Golapganj and Kanaighat in the west, south and east, respectively. The prominent Jaflong Hills range is situated closely to the study area. The area lies within Sylhet Basin agro ecological zone. The weather is mostly humid and heavily dependent on the northern hilly region with a tropical monsoon climate. Haripur gas field is operated by Sylhet Gas Fields Limited, is a pioneer gas and oil Production Company in the country. The blowout accident took place on well Syl-1 and 4 in 1955 and 1962, respectively ${ }^{26}$. Accordingly, the drilling rig was destroyed thoroughly, forming a large deep hole. Successively, the hole was filled with water and made a large pond in the area. Finally, this well was abandoned, but still, gas is seeping continuously from fissures and hillsides surrounding the wells are shown in Fig. 1.

Water samples and analysis. Water samples were collected from 10 different locations around the blowout area is shown in Fig. 2.Then, the samples took in plastic bottles and wrapped adequately with adhesive tape. The dry, clean and sterilized $2 \mathrm{~L}$ plastic bottles were used to carry these samples. After that, samples were brought to the laboratory for analysis. Proper methods and prerequisites have been fulfilled for analysis. Meanwhile, subjective statistical analyses were performed utilizing the given raw data to obtain the results. Besides, phys- 


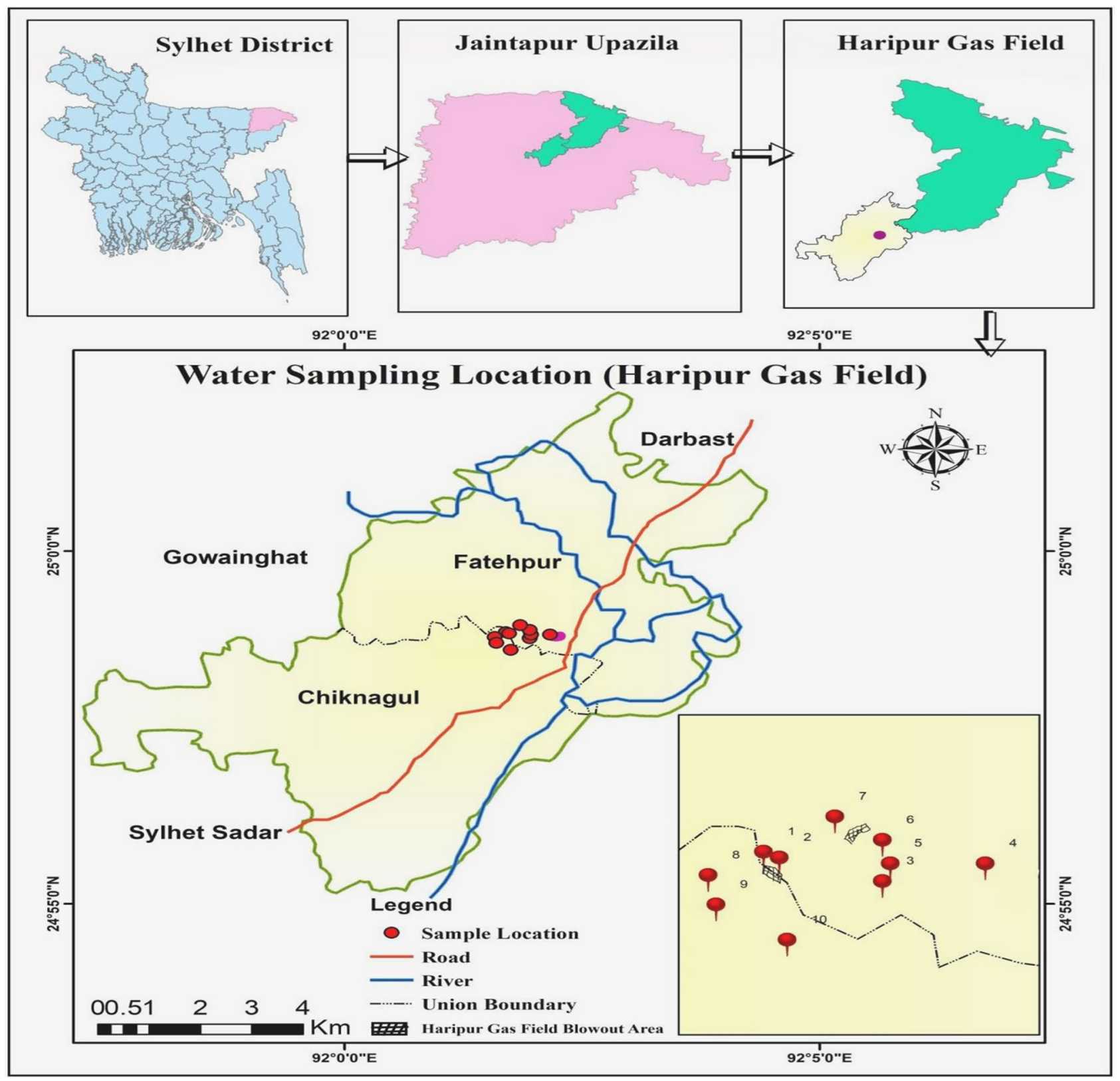

Figure 2. Water sampling locations of the study area.

icochemical parameters were undergone in-situ measurements. In this case, the $\mathrm{pH}$ and Oxidation Reduction Potential (ORP) were tested under HANNA potable Instruments HI 9126. The Electrical conductivity was measured by HANNA EC 215, whereas the turbidity with microprocessor turbidity meter HI 93703 . The concentrations of carbon dioxide, chloride and Total alkalinity were measured by using titration method. The parameters such as total dissolved solids (TDS), total hardness (TH), and $\mathrm{Ca}^{2+}$ have been determined using EDTA titration method. These tests were performed in the laboratory of the Department of Petroleum and Mining Engineering (PME), Shahjalal University of Science and Technology (SUST), Sylhet, Bangladesh. In addition, the water samples have been digested with concentrated $\mathrm{HNO}_{3}$ for trace elements analysis in the laboratory of PME in SUST. After that, the samples were tested in the Soil Research Development Institute (SRDI) in Sylhet to determine Ni, $\mathrm{Cd}, \mathrm{Cu}, \mathrm{Zn}$ and $\mathrm{Pb}$ concentrations in water of the area. The concentrations of trace elements, including $\mathrm{Ni}, \mathrm{Cd}$, $\mathrm{Cu}, \mathrm{Zn}$, and also $\mathrm{Pb}$ were estimated with atomic absorption spectrophotometer (Model: AA-7000, Shimadzu Corporation, Japan) in SRDI, Sylhet. Completing the laboratory analysis, the descriptive statistical analyses were performed by MS Excel (2013). The interrelationship among different water quality parameters were attained by Correlation Matrix ${ }^{27,32}$ and factor analysis ${ }^{32,33}$. In this study, correlation and factor analysis were performed by using IBMSPSS 20. Moreover, the study area map has been constructed using ArcGIS Software, Version 10.3 of 2014. Primarily, the base map was collected from Local Government Engineering Department (LGED) of Bangladesh where they provide open access permission to use $\mathrm{it}^{34}$. To bring out the impact of blowout over the 
areas, the study employed several indices and spatial distribution map to visualization current situation around the area. The risk assessment can profoundly demonstrate the effect of an event on humans and other systems. This study evaluated the ecological risk as well as the health risk from the presence of trace elements (TMs) in the water around the gas field blowout zone. Subsequently, spatial distribution made it more precise through the lens of space.

Water quality index. WQI is a useful way to achieve the nature of water in any region. In this study, WQI was calculated using parameters such as $\mathrm{pH}, \mathrm{EC}$, TDS, TH, turbidity, $\mathrm{Pb}, \mathrm{Ni}, \mathrm{Cu}, \mathrm{Cd}$. The computation of WQI has been conducted by the weighted arithmetic index method ${ }^{35}$. For this computation, the following equations were used:

$$
\begin{gathered}
\mathrm{WQI}=\frac{\sum Q_{n} W_{n}}{\sum W_{n}} \\
\mathrm{Q}_{\mathrm{n}}=\left[\frac{V n}{V s}\right] \times 100 \\
\mathrm{Q}_{\mathrm{PH}}=[\mathrm{Vn}-\mathrm{Vi} / \mathrm{Vs}-\mathrm{Vi}] \times 100 \\
\mathrm{~K}=\frac{1}{\sum V s} \\
\mathrm{~W}_{\mathrm{n}}=\mathrm{k} / \mathrm{Vs}
\end{gathered}
$$

where the parameters: $\mathrm{Q}=$ quality rating of $\mathrm{nth}$ water quality parameter; $\mathrm{W}=$ unit weight of nth water quality parameter; $\mathrm{K}=$ constant of proportionality; $\mathrm{V}_{\mathrm{n}}=$ actual amount of $\mathrm{nth}$ parameter present; $\mathrm{Vi}$ =ideal value of the parameter $[\mathrm{Vi}=0$, except for $\mathrm{pH}(\mathrm{Vi}=7)] ; \mathrm{Vs}=$ standard permissible value for the nth water quality parameter.

The calculated WQI values are classified within a predetermined range where under 50 refers excellent water quality of grade 1, WQI range 51 -100 expresses good water quality of grade 2, WQI range 101-200 denotes poor water quality of grade 3, WQI range 201-300 states very poor water quality of grade 4, and last one, WQI range above 300 refers very bad water quality of grade 5 . In that case, proper treatment would be necessary to use the water for the domestic purpose $\mathrm{e}^{34}$.

Moreover, this study considered the contamination factor ${ }^{36-38}$; pollution load index (PLI) ${ }^{36,39}$; Nemerow multifactor index $(\mathrm{PI})^{36,40,41}$. The ecological risk index $(\mathrm{RI})^{42,43}$ and Heath risk assessment (including Carcinogenic risk as well as Noncarcinogenic risk) were determined as follows. The obtained result from the indices would make significant and specific adjusted output to the system by considering several indicators.

Assessment of health risks using noncarcinogenic and carcinogenic risk analysis. The health risk depends largely on trace elements in water. Its assessment may be categorized as Carcinogenic or Noncarcinogenic $^{44}$. The hazard quotients (HQ) as well as hazard index (HI), and also Incremental lifetime cancer risk (ILCR) were calculated to evaluate carcinogenic or noncarcinogenic risk from trace elements of water sample in the investigated region. It is known that carcinogenic or noncarcinogenic pollutants are exposure hazards sustained in nature for a longer time. From this perspective, the Chronic Daily Intake (CDI) has been determined using equations developed by the Environmental Potential Agency (US EPA) as follows:

$$
\begin{gathered}
\mathrm{CDI}_{\text {ingestion }}=\frac{\mathrm{Cw} * \mathrm{DI} * \mathrm{ABS} * \mathrm{EF} * \mathrm{EP}}{\mathrm{BW} * \mathrm{AT}} \\
\mathrm{CDI}_{\text {dermal }}=\frac{\mathrm{Cw} * \mathrm{SA} * \mathrm{Kp} * \mathrm{ABS} * \mathrm{ET} * \mathrm{EF} * \mathrm{EP} * \mathrm{CF}}{\mathrm{BW} * \mathrm{AT}}
\end{gathered}
$$

where $\mathrm{C}_{\mathrm{w}}=$ concentration of toxic metals $(\mathrm{mg} / \mathrm{L}), \mathrm{K}_{\mathrm{p}}=$ coefficient of permeability $(\mathrm{cm} /$ hour$)$, $A B S=$ factor of dermal absorption (unitless), DI = the amount of daily average intakewater (L/day), ET = time of exposure(h/event), $\mathrm{ED}=$ exposure period (years), $\mathrm{EF}=$ exposure frequency per annual (days/year), $\mathrm{CF}=$ conversion factor $(\mathrm{L} / \mathrm{cm} 3)$, $\mathrm{BW}=$ individual weight $\left(\mathrm{Kg} /\right.$ individual), $\mathrm{SA}=$ skin area available for contact $\left(\mathrm{cm}^{2}\right)$, and $\mathrm{AT}=$ average time (days).

Table 1 represents the estimated value of inputs for assessing chronic daily intake via oral and dermal ingestion $^{44,45}$. A response dose and cancer slope factor values are presented in Table 2.

The Health Quotients (HQ) evaluated by the following equation where CDI and RfD represented chronic daily intake and reference dose (both in $\mathrm{mg} / \mathrm{kg}$ day), respectively.

$$
\text { Health quotients: } \mathrm{HQ}=\frac{C D I}{R f D}
$$

and the sum of the HQ represents the total potential health risks (HI)

$$
\mathrm{HI}=\sum \mathrm{HQ}
$$




\begin{tabular}{|c|c|c|c|}
\hline \multirow[b]{2}{*}{ Parameters } & \multirow[b]{2}{*}{ Units } & \multicolumn{2}{|l|}{ Value } \\
\hline & & Child & Adult \\
\hline Concentration of trace element & $\mu \mathrm{g} / \mathrm{L}$ & - & - \\
\hline Daily average intake & L/day & 1.8 & 2.2 \\
\hline Skin surface area & $\mathrm{cm}^{2}$ & 6600 & 18,000 \\
\hline Exposure time & h/event & 1 & 0.58 \\
\hline Exposure period & years & 6 & $\begin{array}{l}\text { 70(Ingestion) } \\
30 \text { (Dermal) }\end{array}$ \\
\hline Exposure frequency & Day/year & $\begin{array}{l}\text { 365(Ingestion) } \\
\text { 350(Dermal) }\end{array}$ & $\begin{array}{l}\text { 365(Ingestion) } \\
\text { 350(Dermal) }\end{array}$ \\
\hline Average time & days & 2190 & 25,550 \\
\hline Conversion factor & $\mathrm{L} / \mathrm{cm}^{3}$ & 0.001 & 0.001 \\
\hline Individual weight & $\mathrm{kg}$ & 15 & 70 \\
\hline ABS & All & 0.001 & 0.001 \\
\hline Coefficient of permeability & $\mathrm{cm} / \mathrm{h}$ & $\mathrm{Pb}, \mathrm{Cu}, \mathrm{Cd}, \mathrm{Zn}=0.006, \mathrm{Ni}=0.0002$ & $\mathrm{~Pb}, \mathrm{Cu}, \mathrm{Cd}, \mathrm{Zn}=0.006, \mathrm{Ni}=0.0002$ \\
\hline
\end{tabular}

Table 1. The assumed value for CDI evaluation.

\begin{tabular}{|l|l|l|l|}
\hline Elements & RfD oral & RfD dermal & CSF \\
\hline $\mathrm{Pb}$ & 1.4 & 0.42 & 8.5 \\
\hline $\mathrm{Ni}$ & 20 & 5.4 & 0.84 \\
\hline $\mathrm{Cd}$ & 0.5 & 0.005 & 6.1 \\
\hline $\mathrm{Cu}$ & 40 & 12 & - \\
\hline $\mathrm{Zn}$ & 300 & 60 & - \\
\hline
\end{tabular}

Table 2. The response dose and cancer slope factor value $e^{44,45}$.

In the case of the carcinogenic risk evaluated with the formula mention by Mohammadi et al. ${ }^{44}$.

$$
\mathrm{ILCR}=\mathrm{CDI} * \mathrm{CSF}
$$

Here factor, CSF represents as Cancer slope factor (measured in $\mathrm{mg} / \mathrm{kg}$ day) of trace elements in the water. In principle, the computed ratio of $\mathrm{HI}$ is greater than 1 indicates the possible toxic hazards, while the ratio less than 1 denotes no visible toxic effect on human health in the study area.

\section{Outcomes and discussion}

Physiochemical characteristics of water in the blowout region. The physiochemical properties of water were measured in the laboratory. The analyzed properties are shown in Table 3.

The average value of $\mathrm{pH}$ is 6.529 indicates water of the study area is slightly acidic in nature. The average value of $\mathrm{CO}_{2}$ (6.5) complied with the lowering tendency of $\mathrm{pH}$. The average ORP value 36 also reflecting the sign of acidic water in the study region. According to WHO standards (2011), the value of conductivity within range 0-800, Total dissolved solids less than $500 \mathrm{ppm}$, alkalinity $120 \mathrm{ppm}$, and total hardness less than $300 \mathrm{mg} / \mathrm{L}$ are allowable for drinking and domestic purpose ${ }^{37}$. The average value of conductivity $76.7 \mu \mathrm{s} / \mathrm{cm}$, total dissolved solids $44.2 \mathrm{ppm}$, alkalinity 109.1 concurred with the dirking water standard by WHO (2011). The average value of TH is $49 \mathrm{ppm}$ points out that the properties of water are soft.

Spatial distribution of trace elements derived from water bodies around the blowout area. The primary purpose of this study is to understand the concentration level of different Trace metals in the area. In this study, $\mathrm{Pb}, \mathrm{Ni}, \mathrm{Cu}, \mathrm{Cd}$, and $\mathrm{Zn}$ were examined (Fig. 3). Besides the toxic metal spatial distribution map is constructed using the inverse distance weighting (IWD) method in Arc GIS (version 10.5). The map (Fig. 4) shows common patterns of hotspots near the Syl-1 blowout area for every metal. This scenario indicates that these metals are originated from the same source ${ }^{46}$.The contiguous area near Syl-4 well also exhibited a similar pattern to Syl-1 for all metals except Cd. A high concentration of Cd was found closed to the Syl-1 area. The elevated concentration of toxic metals like $\mathrm{Ni}, \mathrm{Pb}$, and $\mathrm{Cd}$ are found in the adjacent areas of blowout points (Fig. 4). Continuous gas escaping from these abandoned wells might stimulate the trace metal accumulation, especially $\mathrm{Pb}$ would be more toxic when it will come to a contact with gasoline (Syl-1 and Syl- 4$)^{7}$. The nonessential toxic metals like $\mathrm{Ni}, \mathrm{Cd}$, and $\mathrm{Pb}$ in water can pose a serious health threat inthesite ${ }^{47}$. In addition, these toxic elements can contribute to acute or chronic health issues like high blood pressure, kidney failure, headache, abdominal pain, cancer, nerve damage, and so on for the long-term consumption of such water ${ }^{48}$.Standard value of $\mathrm{Pb}$ in water is $0.01 \mathrm{mg} / \mathrm{L}, \mathrm{Ni}$ is $0.02 \mathrm{mg} / \mathrm{L}, \mathrm{Cu}$ is $2 \mathrm{mg} / \mathrm{L}, \mathrm{Cd}$ is $0.003 \mathrm{mg} / \mathrm{L}$ in water ${ }^{37}$. In this analysis, the average value of $\mathrm{Pb}=0.04, \mathrm{Cd}=0.05, \mathrm{Ni}=0.16, \mathrm{Cu}=0.03 \mathrm{mg} / \mathrm{L}$, respectively. The TMs like $\mathrm{Zn}$ concentration is about 


\begin{tabular}{|c|c|c|c|c|c|c|c|c|c|}
\hline Samples & pH & $\mathrm{CO}_{2}(\mathrm{ppm})$ & $\begin{array}{l}\text { Turbidity (FTU/ } \\
\text { NTU) }\end{array}$ & $\begin{array}{l}\text { Conductivity }(\mu \mathrm{S} / \\
\mathrm{cm})\end{array}$ & TDS (ppm) & Alkalinity (ppm) & $\begin{array}{l}\text { Total Hardness } \\
\text { (ppm) }\end{array}$ & $\mathrm{Ca}^{2+}(\mathrm{ppm})$ & ORP (mV) \\
\hline SS-1 & 6.63 & 2 & 39.8 & 33 & 21.12 & 115 & 75 & 30.06 & 40.1 \\
\hline SS-2 & 6.51 & 6 & 20.1 & 35.3 & 22.59 & 130 & 45 & 18.04 & 35.6 \\
\hline SS-3 & 6.54 & 7 & 10.8 & 150.1 & 96.06 & 170 & 35 & 14.03 & 34 \\
\hline SS-4 & 6.38 & 7 & 9.6 & 103.8 & 66.43 & 100 & 40 & 16.03 & 42.9 \\
\hline SS-5 & 6.69 & 9 & 4.9 & 105.9 & 67.78 & 90 & 30 & 12.02 & 26.8 \\
\hline SS-6 & 7.5 & 12 & 1.2 & N/A & N/A & 195.24 & 185 & 74.15 & -17.5 \\
\hline SS-7 & 6.4 & 5 & 0.6 & 59.1 & 37.82 & 70 & 20 & 8.02 & 43 \\
\hline SS-8 & 6.37 & 3 & 0.8 & 64.8 & 41.47 & 75 & 15 & 6.01 & 43.4 \\
\hline SS-9 & 6.45 & 10 & 0.5 & 112.8 & 72.19 & 60 & 30 & 12.02 & 39 \\
\hline SS-10 & 5.82 & 4 & 10.3 & 25.8 & 16.51 & 85.71 & 15 & 6.01 & 73 \\
\hline $\operatorname{Max}$ & 7.5 & 12 & 39.8 & 150.1 & 96.06 & 195.24 & 185 & 74.15 & 73 \\
\hline Min & 5.82 & 2 & 0.5 & 25.8 & 16.51 & 60 & 15 & 6.01 & -17.5 \\
\hline Ave & 6.529 & 6.5 & 9.86 & 76.73 & 44.19 & 109.1 & 49 & 19.63 & 36.03 \\
\hline St. dev & 0.42 & 3.17 & 12.24 & 43.21 & 27.66 & 44.34 & 50.92 & 20.41 & 22.35 \\
\hline $\begin{array}{l}\text { WHO standard } \\
\text { (2011) }\end{array}$ & $7-8$ & - & $<5$ & $0-800$ & $<500 \mathrm{ppm}$ & $120 \mathrm{ppm}$ & $300 \mathrm{mg} / \mathrm{L}$ & - & - \\
\hline
\end{tabular}

Table 3. The analyzed physiochemical properties of water. N/A not available.

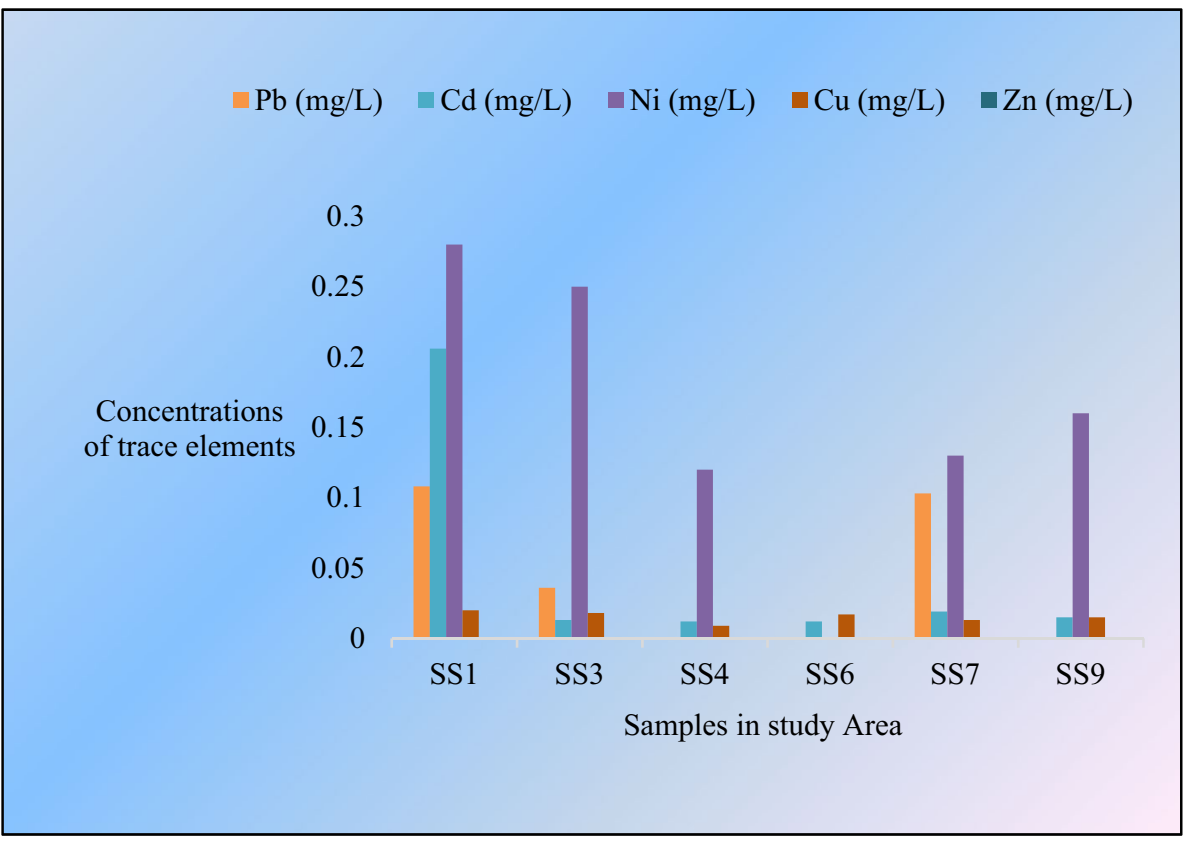

Figure 3. The concentration of trace elements in the study area.

zero or below the detection level for water samples in the study location. The values of $\mathrm{Pb}, \mathrm{Cd}$ and $\mathrm{Ni}$ were higher than the standards level indicates that the water should not be used for any purpose ${ }^{49}$.

Correlation coefficient (R) matrix of water quality parameter presented in the blowout area. A Correlation matrix represents the relationship among several variables. It is generated based on the correlation coefficient, which ranges from -1 to 1 . The value of correlation coefficient $(1,-1)$ indicates perfect correlation, ( -0.9 to -0.7 or $0.9-0.7)$ shows strong correlation, (0.4-0.6 either positive or negative) represents moderate correlation, $(0.1-0.3$ or -0.1 to -0.3$)$ displays as weak and 0 indicates no relationship between variables ${ }^{50}$. The mathematical expressions are described in the article by MacMillan et al. ${ }^{51}$ to evaluate the correlation coefficient $(\mathrm{r})$.

The correlation matrix is shown in Table 4. From the Table 4, it is clear that the $\mathrm{pH}$ shows a moderate to strong correlation with $\mathrm{CO}_{2}(0.63)$ and alkalinity $(0.69)$. Whereas, it shows a very strong positive correlation with Total Hardness (TH) and $\mathrm{Ca}^{2+}(0.88)$, respectively. The moderately positive correlation reflects with EC (0.41) and trace elements $\mathrm{Ni}(0.62)$. The rest of parameters show a negative correlation. The $\mathrm{CO}_{2}$ exhibits a good correlation with $\mathrm{EC}(0.72), \mathrm{TH}$ and $\mathrm{Ca}^{2+}(0.52)$. Alkalinity states a good correlation with $\mathrm{TH}$ and Calcium ions (0.76). EC shows 


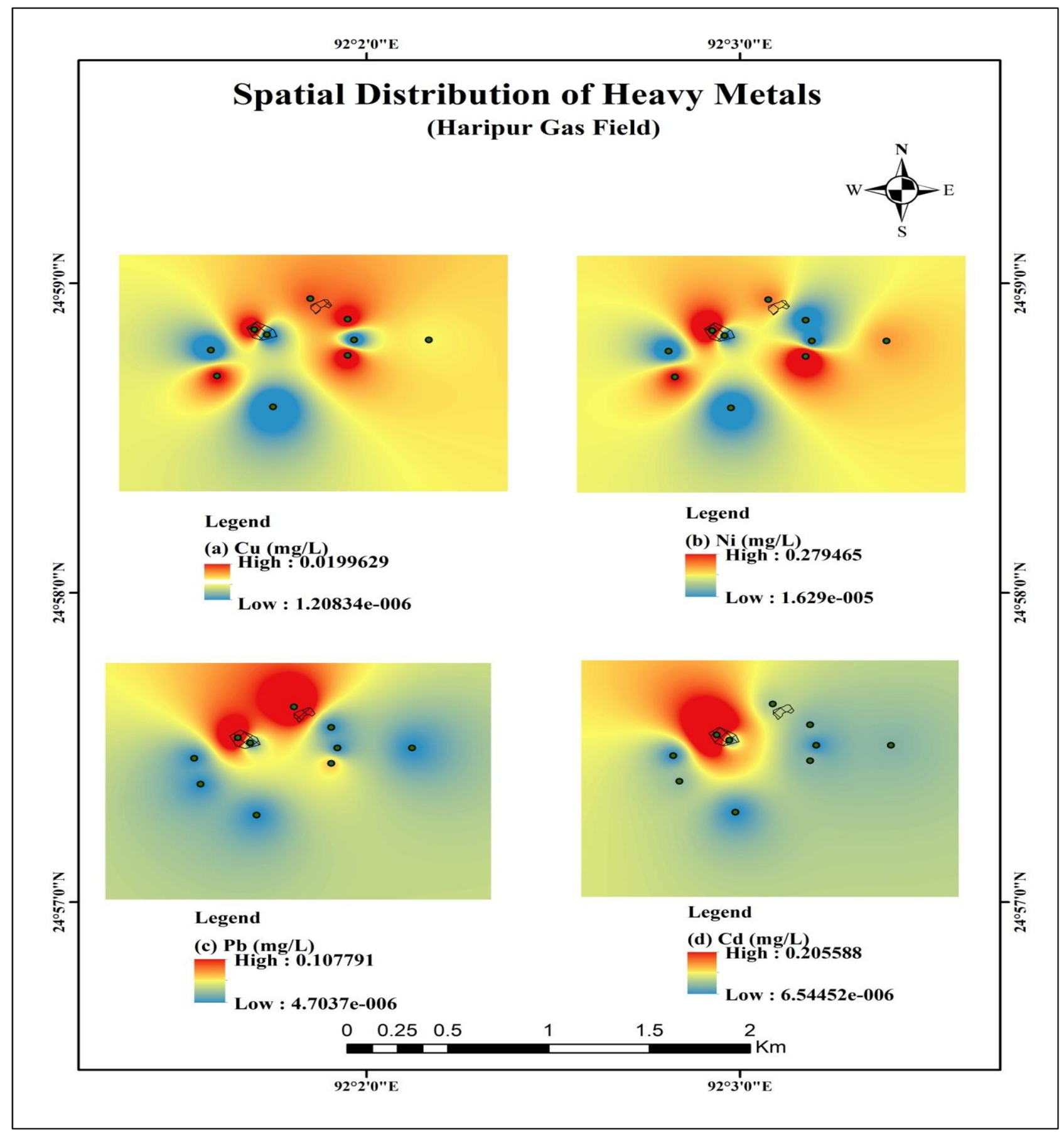

Figure 4. The spatial distribution map of toxic metals in the area.

a maximum correlation with TDS (1.00); maximum correlation also found in the case of TH and $\mathrm{Ca}^{2+}$. Turbidity has a positive correlation for all of the parameters except EC and TDS. TDS shows a strong positive correlation with all of the trace elements, in the case of $\mathrm{Pb}(0.54), \mathrm{Cd}(0.88), \mathrm{Ni}(0.68)$ and for $\mathrm{Cu}$ the value is 0.64 . All trace elements have a strong correlation with each other. $\mathrm{Pb}$ represents a good correlation with $\mathrm{Cd}(0.65), \mathrm{Ni}(0.54)$ and $\mathrm{Cd}(0.35)$. Ni has a strong correlation with $\mathrm{Cd}(0.61), \mathrm{Cu}(0.43)$. Cu also implies a good correlation with $\mathrm{Cd}$ (0.58). In the end, it can be mentioned that a strong positive correlation can be detected among all of the trace elements and also for most of the relative parameters. $\mathrm{CO}_{2}$ established the equilibrium state in the water with ions might be lowering the oxidation. The trace metals $\mathrm{Cu}$ and $\mathrm{Cd}$ were positively correlated with the turbidity. The washed turbid water from the blow out areas might stimulate these trace metals. The inverse association with oxidation and total hardness indicates the less vegetated areas have higher influx rate of soil materials. It implies the result of the correlation matrix indicated that all of the trace elements and also relevant ions presented in the water of blowout area resultant from the same source ${ }^{46}$. 


\begin{tabular}{|c|c|c|c|c|c|c|c|c|c|c|c|c|c|}
\hline & $\mathrm{pH}$ & $\mathrm{CO}_{2}$ & Turbidity & EC & TDS & Alk & TH & $\mathrm{Ca}^{2+}$ & ORP & $\mathbf{P b}$ & Cd & $\mathrm{Ni}$ & $\mathrm{Cu}$ \\
\hline $\mathrm{pH}$ & 1 & & & & & & & & & & & & \\
\hline $\mathrm{CO}_{2}$ & 0.63 & 1 & & & & & & & & & & & \\
\hline Turbidity & -0.07 & -0.54 & 1 & & & & & & & & & & \\
\hline $\mathrm{EC}$ & 0.41 & 0.72 & -0.44 & 1 & & & & & & & & & \\
\hline TDS & -0.22 & 0.18 & -0.24 & $1.00^{*}$ & 1 & & & & & & & & \\
\hline Alk & $0.69^{*}$ & 0.38 & 0.19 & 0.26 & -0.19 & 1 & & & & & & & \\
\hline $\mathrm{TH}$ & $0.88^{* *}$ & 0.52 & 0.07 & -0.13 & -0.52 & $0.76^{*}$ & 1 & & & & & & \\
\hline $\mathrm{Ca}^{2+}$ & $0.88^{\star *}$ & 0.52 & 0.07 & -0.13 & -0.52 & $0.76^{*}$ & $1.0^{* *}$ & 1 & & & & & \\
\hline ORP & $-0.98^{* *}$ & $-0.71^{*}$ & 0.19 & -0.54 & 0.18 & $-0.68^{*}$ & $-0.86^{* *}$ & $-0.86^{* *}$ & 1 & & & & \\
\hline $\mathrm{Pb}$ & -0.17 & -0.48 & 0.54 & -0.50 & -0.13 & -0.62 & -0.27 & -0.27 & 0.29 & 1 & & & \\
\hline $\mathrm{Cd}$ & -0.08 & -0.75 & $0.88^{* *}$ & -0.58 & -0.33 & -0.23 & 0.06 & 0.06 & 0.28 & $0.65^{*}$ & 1 & & \\
\hline $\mathrm{Ni}$ & 0.16 & -0.48 & 0.68 & -0.75 & -0.60 & 0.13 & 0.19 & 0.19 & -0.04 & $0.54^{*}$ & $0.61^{*}$ & 1 & \\
\hline $\mathrm{Cu}$ & -0.08 & -0.49 & $0.64^{*}$ & $-0.91^{*}$ & -0.69 & -0.37 & 0.16 & 0.18 & 0.18 & $0.35^{*}$ & $0.59^{*}$ & $0.43^{*}$ & 1 \\
\hline
\end{tabular}

Table 4. Correlation coefficient matrix of water parameters. ${ }^{\star}$ Correlation is significant at the 0.05 level. ${ }^{*}$ Correlation is significant at the 0.01 level.

\begin{tabular}{|l|r|r|}
\hline \multirow{2}{*}{ Water parameters } & \multicolumn{2}{|l|}{ Components } \\
\cline { 2 - 3 } & \multicolumn{1}{l|}{1} & \multicolumn{1}{l|}{} \\
\hline $\mathrm{PH}$ & 0.239 & 0.939 \\
\hline $\mathrm{CO}_{2}$ & -0.923 & 0.242 \\
\hline Turbidity & 0.966 & -0.089 \\
\hline $\mathrm{EC}$ & -0.876 & -0.033 \\
\hline $\mathrm{TDS}$ & -0.876 & -0.033 \\
\hline $\mathrm{Alkalinity}$ & -0.173 & -0.266 \\
\hline $\mathrm{TH}$ & 0.965 & -0.143 \\
\hline $\mathrm{Ca}{ }^{2+}$ & 0.965 & -0.143 \\
\hline $\mathrm{ORP}$ & 0.436 & -0.875 \\
\hline $\mathrm{Pb}$ & 0.572 & 0.773 \\
\hline $\mathrm{Cd}$ & 0.895 & 0.105 \\
\hline $\mathrm{Ni}$ & 0.765 & 0.378 \\
\hline $\mathrm{Cu}$ & 0.829 & -0.227 \\
\hline
\end{tabular}

Table 5. Principal components analysis results of water parameters. Extraction method: principal component analysis and only 2 components extracted.

Factor loading of water parameters. The interrelationship within a set of variables or objects is represented by factor analysis. The factors contain all of the basic information about a wider set of variables or observed objects. It shows how the variables are strongly correlated with the determined factor. Factor analysis is also known as a multivariate approach to reducing data ${ }^{33}$. Among different types of factor analysis, Principal component analysis account for the maximum variance of observed variables. So, it can be called varianceoriented $^{33}$. Factor loading shows how certain variables strongly correlate for a given factor. Factor loading varies from -1 to +1 where the value of factor loading below -0.5 or above 0.5 suggested good correlations and value closed to -1 or +1 , suggesting a more robust correlation ${ }^{32}$. The Table 5 represented the principal component analysis result of factor solution.

From analysis (Table 5), it can be realized that the water quality parameters such as Turbidity, TH, $\mathrm{Ca}^{2+}, \mathrm{Cd}$, $\mathrm{Ni}$ and $\mathrm{Cu}$ have a stronger correlation with each other's reflecting their source of origin might be from the same area $^{14}$. Factor loading also suggested that more robust interconnection exists among $\mathrm{CO}_{2}$, EC and TDS. In this analysis, the two-factor solution explained approximately $80.6 \%$ of the variance. The eigenvalue, total variance explained are represented in Supplementary Table S1. That percentage is high enough to accept the results. It can also be added that the red and yellow colored loading represented strong correlation with each other ${ }^{46,52}$.

Water quality index (WQI). The WQI is one of the best tools for monitoring the surface-groundwater contamination and can be used for water quality improvement programs. The WQI is determined from various physicochemical parameters like $\mathrm{pH}, \mathrm{EC}$, TDS, TH, EC, and so forth. Higher estimation of WQI indicates poor water quality and lower estimation of WQI shows better water quality. During this examination, WQI esteems a range from 0.02633 to 5144.37 and are characterized into five water types shown in Table 6 . The noteworthy WQI is recorded in case of (sample-1) which demonstrates an elevated level of contamination. Water 


\begin{tabular}{|l|r|l|l|}
\hline Samples & \multicolumn{1}{|c|}{ WQI } & Remarks & Category for water \\
\hline 1 & \multicolumn{1}{|c|}{5144.3} & Proper treatment required before use & 5 \\
\hline 2 & 0.17 & Excellent & 1 \\
\hline 3 & 1223.7 & Proper treatment required before use & 5 \\
\hline 4 & 655.55 & Proper treatment required before use & 5 \\
\hline 5 & 0.06 & Excellent & 1 \\
\hline 6 & 231.09 & Very poor & 4 \\
\hline 7 & 1004.1 & Proper treatment required before use & 5 \\
\hline 8 & 0.03 & Excellent & 1 \\
\hline 9 & 854.71 & Proper treatment required before use & 5 \\
\hline 10 & 0.09 & Excellent & 1 \\
\hline Avg & 911.38 & Proper treatment required before use & 5 \\
\hline
\end{tabular}

Table 6. Classification of the water quality index for individual parameter of water.

\begin{tabular}{|l|l|l|l|l|l|}
\hline Samples & Pb & Cd & Ni & Cu & Zn \\
\hline Contamination factor \\
\hline SS1 & 10.80 & 68.67 & 14.00 & 0.01 & - \\
\hline SS3 & 3.6 & 4.33 & 12.50 & 0.009 & - \\
\hline SS4 & - & 4.00 & 6.00 & 0.0045 & - \\
\hline SS6 & - & 4.00 & - & 0.0085 & - \\
\hline SS7 & 10.30 & 6.33 & 6.50 & 0.0065 & - \\
\hline SS9 & - & 5.00 & 8.00 & 0.0075 & - \\
\hline
\end{tabular}

Table 7. Contamination factor of water samples.

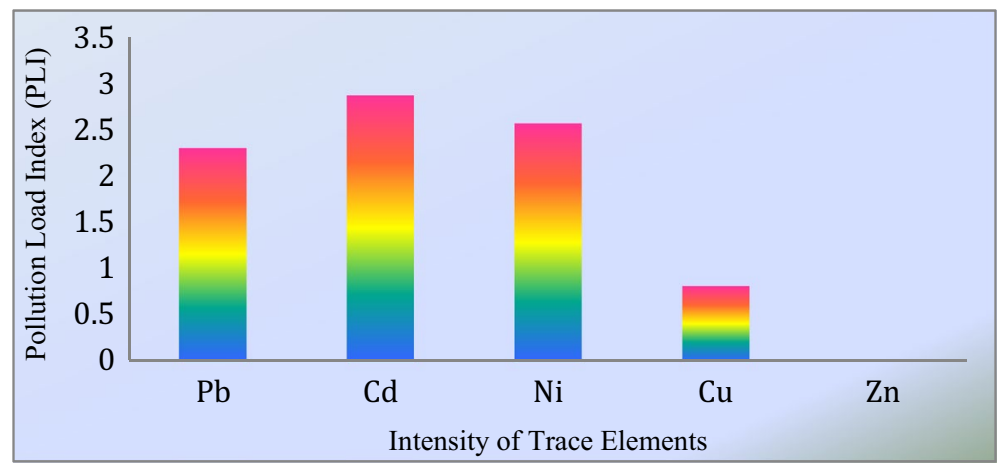

Figure 5. Pollution load index of the study area.

sample 2, 5, 8 and 10 are grouped under class- 1 which demonstrates there is a lower degree of pollution in water. In addition, WQI calculation for sample 2, 5, 8 and 10 excluded trace elements value and WQI evaluation for sample 1, 3, 4, 6, 7 and 9 included the heavy metals value in water. These results also clarify the association of heavy metals on water quality degradation of the study area.

The situation of contamination in the area. The level of contamination has been demonstrated in terms of the CFi, PLI, and also PI analysis of water samples around the blowout area. The values of CFi are indicated the degree of contamination. The intensity of CFi has been determined with some numerical values like 1,3 , and 6 . The CFi value is less than 1 , which implies low contamination, as the value is $>6$ indicated a high degree of contamination ${ }^{36}$. The Table 7 elucidates that the degree of contamination in the case of trace elements $\mathrm{Pb}, \mathrm{Cd}$, and $\mathrm{Ni}$ are very high for most of the locations of the research sides. Besides $\mathrm{Cu}$ and $\mathrm{Zn}$ exhibit that level contamination is low in the area. In other cases, the PLI can be evaluated by using the CFi value. The value of PLI greater than 1 symbolizes polluted and less than 1 represents the unpolluted status ${ }^{36,39}$. The pollution load index rate of $\mathrm{Pb}, \mathrm{Cd}$, and $\mathrm{Ni}$ are 2.3,2.87, and 2.56, respectively (Fig. 5). This result indicates the pollution of water bod- 


\begin{tabular}{|l|l|l|l|l|}
\hline Sample & Pb & Cd & Ni & Cu \\
\hline \multicolumn{5}{|l|}{ The potential ecological risk index } \\
\hline SS1 & 54 & 2060 & 70 & 0.05 \\
\hline SS3 & 18 & 130 & 62.5 & 0.045 \\
\hline SS4 & 0 & 120 & 30 & 0.023 \\
\hline SS6 & 0 & 120 & 0 & 0.043 \\
\hline SS7 & 51.5 & 190 & 32.5 & 0.033 \\
\hline SS9 & 0 & 150 & 40 & 0.033 \\
\hline RI & 123.5 & 2770 & 235 & 0.190 \\
\hline
\end{tabular}

Table 8. Ecological risk index (RI) of the study area.

ies in the sampling sites. The other elements such as $\mathrm{Cu}$ and $\mathrm{Zn}$ are within the allowable limit are shown in Fig. 5. Moreover, the PI indicates similar results as CFi and PLI.

The state of potential ecological threat in the area. The ecological potential risk index has been appealed to detect the possible threat to the ecological system in the adjoining area. The calculated RI value provided the risk factor of water for understanding the ecological threat. When the RI value is more than 600 , it is considered a polluted case $\mathrm{e}^{11,14,36}$. The computed $\mathrm{RI}$ value of the study for $\mathrm{Pb}, \mathrm{Cd}, \mathrm{Ni}$, and $\mathrm{Cu}$ are $123.5,2770,235$, and 0.23 , respectively (Table 8 ). The value of $\mathrm{Cd}$ is high enough $(\mathrm{RI}>600)$. So, the Cd values indicated that the potential threat to the ecological system. Besides, the TMs like $\mathrm{Ni}$ and $\mathrm{Cu}$ are specified medium to low ecological pollution in the area are shown in Table 8. Moreover, the spatial distribution has been presented to outlook the potential ecological threats around the blow out location of the gas field is shown in Fig. 6.

The spatial distribution map of RI also pointed out the high ecological risk closed to the blowout areas (Fig. 6). From these results, it can be implied that the use of this water for domestic or drinking purposes, can be harmful for living beings. Moreover, it can be distressed the ecological system in the site. Hence, the use of the water from this site should be avoided by dwellers near the blowout areas of the gas field.

Assessment of noncarcinogenic health risks. Noncarcinogenic risk is one of the vital categories of human health risk assessment. It is known that a polluted environment is highly liable for causing a health risk. Toxic metal presents in water also very harmful for public health, including child and adult both. The health risks may be extended through ingestion and skin absorption of water. To know the harmful impacts of trace elements of water on the human body, noncarcinogenic risk evaluation is more important. For that, the value of CDI for ingestion and dermal absorption was evaluated at the beginning to identify such risk index (Supplementary Table S2 and S3). Then the CDI has been divided with the RfD value. From where, the HQ can be acquired separately for ingestion and dermal absorption. The summation of $\mathrm{HQ}_{\text {ingestion }}$ and $\mathrm{HQ}_{\text {dermal }}$ expressed the $\mathrm{HQ}_{\text {total }}$. And the $\mathrm{HQ}_{\text {total }}$ entirety was used to achieve the HI are shown in Table 9.

The results elucidate that case of adult, the mean value of $\mathrm{CDI}_{\text {Total }}$ for $\mathrm{Pb}$ is $1.29 \mathrm{E}-03, \mathrm{Cd}$ is $1.45 \mathrm{E}-03, \mathrm{Ni}$ is 4.93E-03 and $\mathrm{Cu}$ is $4.83 \mathrm{E}-04$, respectively. For the child, the mean value of $\mathrm{CDI}_{\text {Total }}$ in the case of $\mathrm{Pb}, \mathrm{Cd}, \mathrm{Ni}$, and CU is 4.7544E-03, 5.33E-03, 1.81E-03 and 1.77E-04, correspondingly. Additionally, the order of CDI $\mathrm{T}_{\text {Total }}$ for adults are $\mathrm{Ni}>\mathrm{Cd}>\mathrm{Pb}>\mathrm{Cu}$ (Supplementary Table S2) whereas, for child, it is quite different. In the case of children, the order are $\mathrm{Cd}>\mathrm{Pb}>\mathrm{Ni}>\mathrm{Cu}$ are presented in Supplementary Table S3.

The mean values of $\mathrm{HQ}_{\mathrm{Total}}$ of $\mathrm{Pb}, \mathrm{Cd}, \mathrm{Cu}$, and Ni are ranging from $4.46 \mathrm{E}-05$ to $1.45 \mathrm{E}-02$ for child. Besides, these values for adults are extending from $1.21 \mathrm{E}-05$ to $4.66 \mathrm{E}-03$. These values suggest that the trace elements in the water of the study area are quite harmful to the child than an adult. The children's $\mathrm{HQ}_{\text {Total }}$ has been ordered as $\mathrm{Cd}>\mathrm{Pb}>\mathrm{Ni}>\mathrm{Cu}$ and for the adult $\mathrm{Cu}<\mathrm{Ni}<\mathrm{Pb}<\mathrm{Cd}$ using the mean values of water in the blowout area. The minimum, maximum and mean values of $\mathrm{HI}$ for children are $3.82 \mathrm{E}-03,7.55 \mathrm{E}-02$, and $2.41 \mathrm{E}-02$, respectively. And for adults, these values are 9.15E-04, 1.84E-02, and 4.65E-03. At this point, the mean value of HQs and HI of the study are less than 1, which defines that there is no adverse health-hazardous threat due to the exposure of toxic metals ${ }^{53}$. Hence from this computation, it can be concluded that noncarcinogenic risks are minor for the public health around the blowout area of Haripur Gas Field.

Carcinogenic health risk evaluation. The excess TMs in water, soil or foods are blamed for causing the risk for ecology and health. These elements can cause cancer in the case of drinking such water for a long time. In this article, the values of ILCR of TMs in the areas are shown in Table 10. It is recognized that the ILCR value less than $1 \times 10^{-6}$ can be considered as insignificant event to cause disease ${ }^{11,44}$. At this time, the risk of cancer can be neglected. Whereas, the values of ILCR more than $1 \times 10^{-4}$ can be considered as significant to cause cancer like disease ${ }^{11,14,44}$.

The ILCR values of the trace elements are presented in Table 10.This Table also displays the mean, maximum, and minimum ILCR values for children as well as adults. The mean values of $\mathrm{Pb}$, Cd and Ni for adults are $2.20 \times 10^{-2}, 8.87 \times 10^{-3}, 4.06 \times 10^{-3}$, respectively. But, these values for children are $8.08 \times 10^{-2}, 3.25 \times 10^{-2}$, and $1.82 \times 10^{-2}$, respectively. The mean ILCR values of $\mathrm{Cd}$ and $\mathrm{Ni}$ (Fig. 7) are harmful and $\mathrm{Pb}$ values represented more harmful for children ${ }^{45}$. For Adults, the ILCR values of $\mathrm{Cd}$ and $\mathrm{Ni}$ are also significant and $\mathrm{Pb}$ is more noticeable to cause health risk (Fig. 7) 7,13,36,42. The carcinogenic risk of these elements can be ranked as $\mathrm{Pb}>\mathrm{Cd}>\mathrm{Ni}$. 


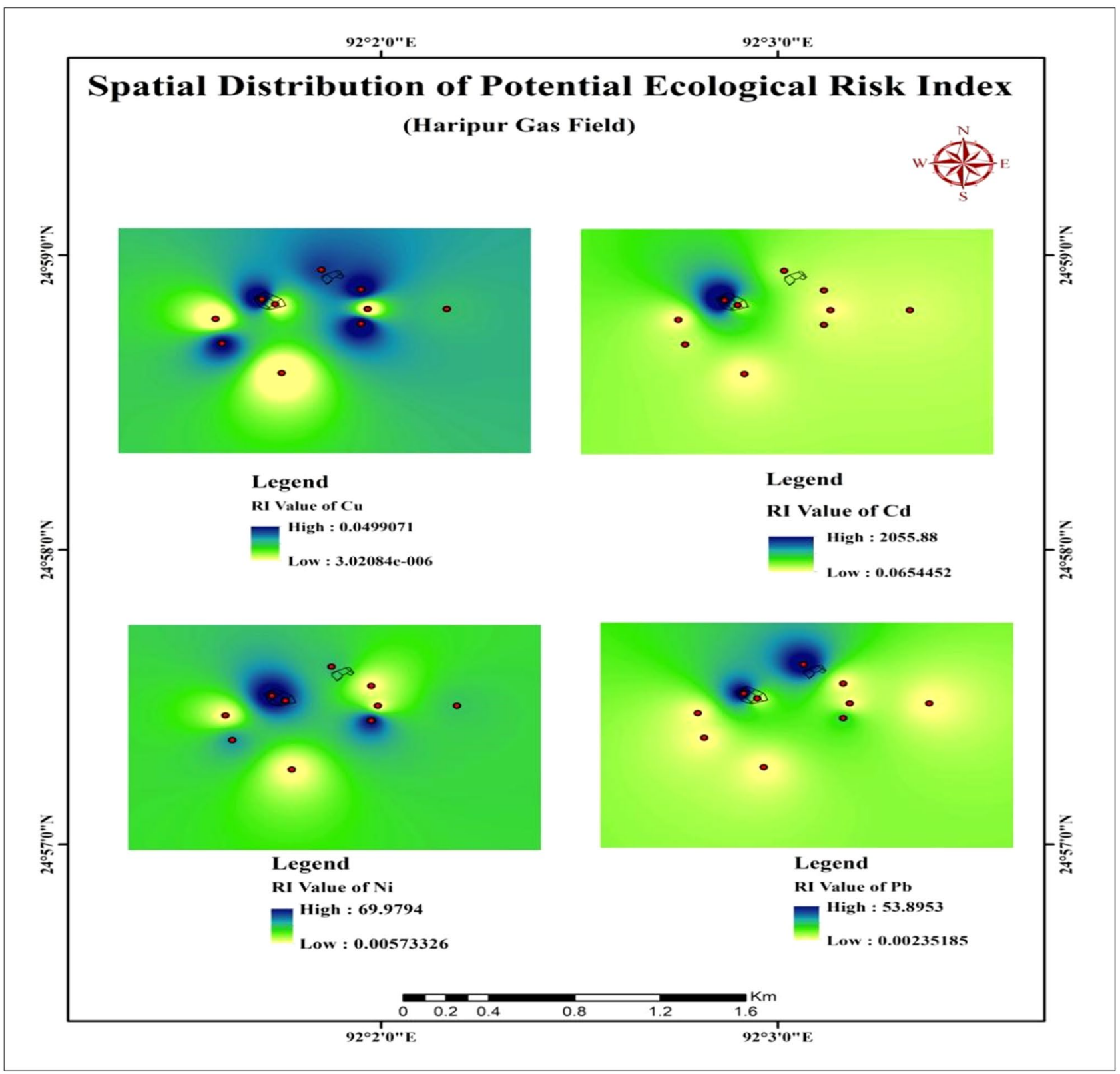

Figure 6. A map of the spatial distribution of potential ecological risk threats in the study area.

\begin{tabular}{|l|l|l|l|l|l|l|l|l|l|l|}
\hline HQ total & \multicolumn{1}{l}{ For child } & \multicolumn{1}{l|}{ For adult } \\
\hline Samples & Pb & Cd & Ni & Cu & HI & Pb & Cd & Ni & Cu & HI \\
\hline SS1 & $8.99 \mathrm{E}-03$ & $6.48 \mathrm{E}-02$ & $1.63 \mathrm{E}-03$ & $5.82 \mathrm{E}-05$ & $7.55 \mathrm{E}-02$ & $2.44 \mathrm{E}-03$ & $1.55 \mathrm{E}-02$ & $4.41 \mathrm{E}-04$ & $1.58 \mathrm{E}-05$ & $1.84 \mathrm{E}-02$ \\
\hline SS3 & $3.00 \mathrm{E}-03$ & $4.09 \mathrm{E}-03$ & $1.46 \mathrm{E}-03$ & $5.24 \mathrm{E}-05$ & $8.59 \mathrm{E}-03$ & $8.13 \mathrm{E}-04$ & $9.77 \mathrm{E}-04$ & $3.93 \mathrm{E}-04$ & $1.42 \mathrm{E}-05$ & $2.20 \mathrm{E}-03$ \\
\hline SS4 & - & $3.77 \mathrm{E}-03$ & $7.00 \mathrm{E}-04$ & $2.62 \mathrm{E}-05$ & $4.50 \mathrm{E}-03$ & - & $9.01 \mathrm{E}-04$ & $1.61 \mathrm{E}-04$ & $7.12 \mathrm{E}-06$ & $1.07 \mathrm{E}-03$ \\
\hline SS6 & - & $3.77 \mathrm{E}-03$ & - & $4.95 \mathrm{E}-05$ & $3.82 \mathrm{E}-03$ & - & $9.01 \mathrm{E}-04$ & - & $1.34 \mathrm{E}-05$ & $9.15 \mathrm{E}-04$ \\
\hline SS7 & $8.57 \mathrm{E}-03$ & $5.98 \mathrm{E}-03$ & $7.48 \mathrm{E}-04$ & $3.79 \mathrm{E}-05$ & $1.53 \mathrm{E}-02$ & $2.33 \mathrm{E}-03$ & $1.43 \mathrm{E}-03$ & $2.05 \mathrm{E}-04$ & $1.03 \mathrm{E}-05$ & $3.97 \mathrm{E}-03$ \\
\hline SS9 & - & $4.72 \mathrm{E}-03$ & $9.33 \mathrm{E}-04$ & $4.37 \mathrm{E}-05$ & $5.69 \mathrm{E}-03$ & - & $1.13 \mathrm{E}-03$ & $2.52 \mathrm{E}-04$ & $1.19 \mathrm{E}-05$ & $1.39 \mathrm{E}-03$ \\
\hline Min & $3.00 \mathrm{E}-03$ & $3.77 \mathrm{E}-03$ & $7.00 \mathrm{E}-04$ & $2.62 \mathrm{E}-05$ & $3.82 \mathrm{E}-03$ & $8.13 \mathrm{E}-04$ & $9.01 \mathrm{E}-04$ & $1.61 \mathrm{E}-04$ & $7.12 \mathrm{E}-06$ & $9.15 \mathrm{E}-04$ \\
\hline Max & $8.99 \mathrm{E}-03$ & $6.48 \mathrm{E}-02$ & $1.63 \mathrm{E}-03$ & $5.82 \mathrm{E}-05$ & $7.55 \mathrm{E}-02$ & $2.44 \mathrm{E}-03$ & $1.55 \mathrm{E}-02$ & $4.41 \mathrm{E}-04$ & $1.58 \mathrm{E}-05$ & $1.84 \mathrm{E}-02$ \\
\hline Mean & $6.85 \mathrm{E}-03$ & $1.45 \mathrm{E}-02$ & $1.09 \mathrm{E}-03$ & $4.46 \mathrm{E}-05$ & $2.41 \mathrm{E}-02$ & $1.86 \mathrm{E}-03$ & $3.47 \mathrm{E}-03$ & $2.90 \mathrm{E}-04$ & $1.21 \mathrm{E}-05$ & $4.65 \mathrm{E}-03$ \\
\hline
\end{tabular}

Table 9. The HQ and hazard index (HI) value of noncarcinogenic analysis of the area. 


\begin{tabular}{|l|l|l|l|l|l|l|}
\hline \multirow{2}{*}{ Samples } & \multicolumn{9}{l}{ For adult } & Pb & Cd & Ni & For children & Cd & Ni \\
\hline ILCR & Pb & \multicolumn{7}{l|}{} \\
\hline SS1 & $2.89 \mathrm{E}-02$ & $3.96 \mathrm{E}-02$ & $7.39 \mathrm{E}-03$ & $1.06 \mathrm{E}-01$ & $1.45 \mathrm{E}-01$ & $2.72 \mathrm{E}-02$ \\
\hline SS3 & $9.64 \mathrm{E}-03$ & $2.50 \mathrm{E}-03$ & $6.60 \mathrm{E}-03$ & $3.53 \mathrm{E}-02$ & $9.16 \mathrm{E}-03$ & $2.43 \mathrm{E}-02$ \\
\hline SS4 & - & $2.31 \mathrm{E}-03$ & $2.69 \mathrm{E}-03$ & - & $8.45 \mathrm{E}-03$ & $1.16 \mathrm{E}-02$ \\
\hline SS6 & - & $2.31 \mathrm{E}-03$ & - & - & $8.45 \mathrm{E}-03$ & - \\
\hline SS7 & $2.76 \mathrm{E}-02$ & $3.65 \mathrm{E}-03$ & $3.43 \mathrm{E}-03$ & $1.01 \mathrm{E}-01$ & $1.34 \mathrm{E}-02$ & $1.26 \mathrm{E}-02$ \\
\hline SS9 & - & $2.88 \mathrm{E}-03$ & $4.23 \mathrm{E}-03$ & - & $1.06 \mathrm{E}-02$ & $1.55 \mathrm{E}-02$ \\
\hline
\end{tabular}

Table 10. ILCR value of trace element presents in the water sample.
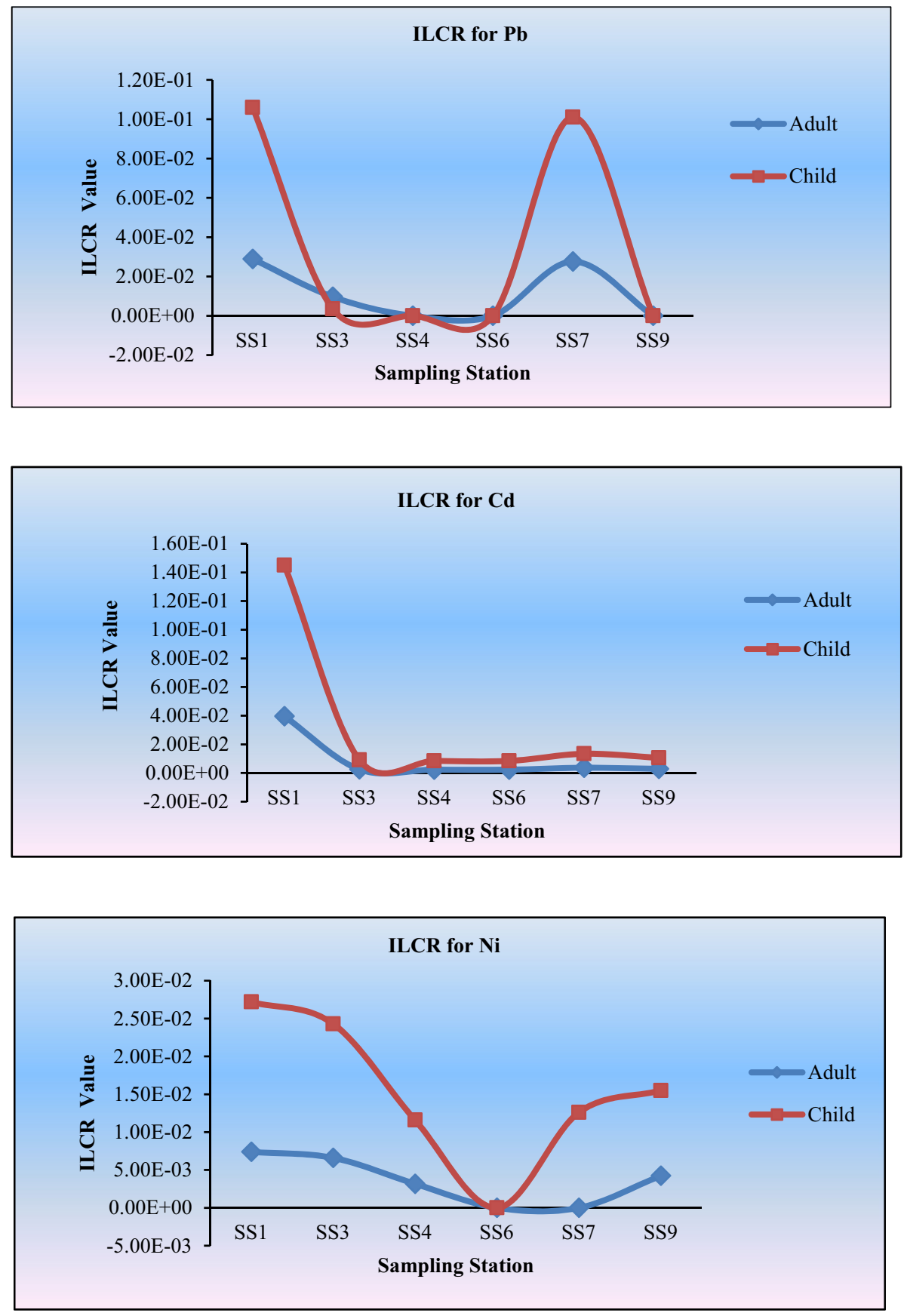

Figure 7. The incremental lifetime cancer risk (ILCR) for TMs in the blowout area. 
A study carried out by Xu et al. ${ }^{54}$ where shown that the pollution status from an oil-based drill cuttings field. The result of that study revealed that the metal pollution was moderate and also noticed that the noncarcinogenic and carcinogenic risks of drilling workers were within the permissible level. The present research implied the same as that the blown-out areas were out of the health exposure except for children. Besides, another study led by Guan et al..$^{55}$ in a mining area found an uneven distribution of potential ecological risk. However, this article addressed this gap considering risk assessment indices and spatial distribution of trace metals in a comprehensive way which could be a good foundation for future study in this field.

\section{Concluding remarks}

The study assessed the ecological and health risks closed to the Haripur gas field well blowout area. The physicochemical properties and TMs such as $\mathrm{Pb}, \mathrm{Ni}, \mathrm{Cd}, \mathrm{Cu} \mathrm{Zn}$ were analyzed in the laboratory. According to physicochemical analysis, the water is slightly acidic and not suitable the drinking purpose. The computation of WQI indicated that proper treatment is necessary before using the water of the study area. The result of TMs analysis are shown that the average concentrations of $\mathrm{Pb}, \mathrm{Ni}$ and $\mathrm{Cd}$ were within the WHO standard limit. Besides, $\mathrm{Cu}$ and $\mathrm{Zn}$ concentrations also belong to the permissible limit. The contamination factor values of $\mathrm{Pb}, \mathrm{Cd}$, and $\mathrm{Ni}$ are high, whereas $\mathrm{Cu}$ and $\mathrm{Zn}$ are low.

The correlation and factor loading show that the significant relationships among various parameters. The correlation of TDS with $\mathrm{Pb}(0.54), \mathrm{Ni}(0.68), \mathrm{Cd}(0.88)$, and $\mathrm{Cu}(0.64)$ reflected high interrelationship to one another. Also all TMs have a stronger correlation with each other. Furthermore factor analysis suggested stronger interconnection exists among turbidity, $\mathrm{TH}, \mathrm{Ca}^{2+}, \mathrm{Cd}, \mathrm{Ni}, \mathrm{Cu}$, and so on implied that all of the TMs may be originated from same source.

The pollution load index value for $\mathrm{Pb}$ (2.30), $\mathrm{Cd}$ (2.87), and $\mathrm{Ni}$ (2.56) show the pollution, whereas $\mathrm{Cu}(0.68)$ and $\mathrm{Zn}$ characterized unpolluted water bodies in the area. The multi-factor index also represents a quite similar indication with PLI. The potential ecological risk index for $\mathrm{Cd}(2770)$ is greater than 600 , expressing the ecological pollution. But in the case of $\mathrm{Ni}(235), \mathrm{Pb}(123.5)$ and $\mathrm{Cu}(0.23)$ implicate the negligible ecological pollution closed to blowout areas. The ILCR mean value of $\mathrm{Cd}, \mathrm{Ni}$, and $\mathrm{Pb}$ for an adult is higher than $1 \mathrm{E}-06$ which stands fora significant risk. The value of $\mathrm{Pb}$ for an adult is more significant than others. On the other hand, the CDI and HQ value of TMs from the noncarcinogenic index are positioned as $\mathrm{Cd}>\mathrm{Pb}>\mathrm{Ni}>\mathrm{Cu}>\mathrm{Zn}$. Besides, the values of the Hazard Index for the child is $1.89 \mathrm{E}-02$ and for an adult is $4.65 \mathrm{E}-03$. The mean value of HQ and $\mathrm{HI}$ are less than one implied that the noncarcinogenic health risk is negligible by exposing the TMs to public health through ingestion and dermal absorption. Nonetheless, this study discouraged the dwellers to drink this water from blowout areas. Additionally, the outcomes of the article will play a vial role to have the proper water pollution management, monitoring, and community awareness for controlling the ecological-health risk in and around the blowout as well as other industrial areas in Bangladesh.

Received: 22 December 2020; Accepted: 16 July 2021

Published online: 02 August 2021

\section{References}

1. Kelly, W. R., Matisoff, G. \& Fisher, J. B. The effects of a gas well blow out on groundwater chemistry. Environ. Geol. Water Sci. 7(4), 205-213. https://doi.org/10.1007/BF02509921 (1985).

2. SGFL (Sylhet Gas Field Limited, 2019). http://sgfl.org.bd/site/page/cfaa7cff-c756-44fc-8d77-3bfbe5d58c5f/. Accessed 15 Jan 2019.

3. Bose, S. Environmental accounting and reporting in fossil fuel sector: A study on Bangladesh Oil, Gas and Mineral Corporation (Petrobangla). Cost Manag 34(2), 53-67 (2006).

4. Imam, B. Energy Resources of Bangladesh 2nd edn. (University Grants Commission of Bangladesh, 2013).

5. Gazprom (2019). http://www.gazprominfo.com/terms/emissions-of-oil-and-gas/. Accessed 12 June 2019.

6. Kazi, T. G. et al. Assessment of water quality of polluted lake using multivariate statistical techniques: A case study. Ecotoxicol. Environ. Saf. 72(2), 301-309. https://doi.org/10.1016/j.ecoenv.2008.02.024 (2009).

7. Su, H., Kang, W., Xu, Y. \& Wang, J. Assessment of groundwater quality and health risk in the oil and gas field of Dingbian County, Northwest China. Expo Health 9, 227-242. https://doi.org/10.1007/s12403-016-0234-6 (2017).

8. Shang, H. et al. An ecology-oriented exploitation mode of groundwater resources in the northern Tianshan Mountains, China. J. Hydrol. 543(1), 386-394. https://doi.org/10.1016/j.jhydrol.2016.10.012 (2016).

9. Wu, J., Lu, J., Li, L., Min, X. \& Luo, Y. Pollution, ecological-health risks, and sources of toxic metals in soil of the northeastern Qinghai-Tibet Plateau. Chemosphere https://doi.org/10.1016/j.chemospHere.2018.02.122 (2018).

10. Jiang, H. et al. Toxic metal levels in fish from heilongjiang river and potential health risk assessment. Bull. Environ. Contam. Toxicol. 97(4), 536-542 (2016).

11. Mostafiz, F. et al. Bioaccumulation of trace metals in freshwater prawn, Macrobrachium rosenbergii from farmed and wild sources and human health risk assessment in Bangladesh. Environ. Sci. Pollut. Res. 27, 16426-16438 (2020).

12. Cheng, W. et al. GeograpHic distribution of toxic metals and identification of their sources in soils near large, open-pit coal mines using positive matrix factorization. J. Hazard. Mater. 387, 121666. https://doi.org/10.1016/j.jhazmat.2019.121666 (2020).

13. Johnbosco, C. E. Groundwater quality assessment using pollution index of groundwater (PIG), ecological risk index (ERI) and hierarchical cluster analysis (HCA): A case study. Groundw. Sustain. Dev. 10, 1-8. https://doi.org/10.1016/j.gsd.2019.100292 (2020).

14. Li, T. et al. Source apportionment and source-to-sink transport of major and trace elements in coastal sediments: Combining positive matrix factorization and sediment trend analysis. Sci. Total Environ. 651(1), 344-356. https://doi.org/10.1016/j.scitotenv. 2018.09.19 (2019).

15. Akter, S., Howladar, M. F., Ahmed, Z. \& Chowdhury, T. R. The rainfall and discharge trends of Surma River area in North-eastern part of Bangladesh: An approach for understanding the impacts of climatic change. Environ. Syst. Res. 8, 28. https://doi.org/10. 1186/s40068-019-0156-y (2019).

16. Wu, S. et al. Levels and health risk assessments of toxic metals in urban soils in Dongguan, China. J. Geochem. Explor. 148, 71-78. https://doi.org/10.1016/j.gexplo.2014.08.009 (2015).

17. Okoro, E. E., Okolie, A. G., Sanni, S. E. \& Omeje, M. Toxicology of heavy metals to subsurface lithofacies and drillers during drilling of hydrocarbon wells. Sci. Rep. 10(1), 1-13 (2020). 
18. Giri, S. \& Singh, A. K. Assessment of surface water quality using heavy metal pollution index in Subarnarekha River, India. Water Qual. Exposure Health 5, 173-182. https://doi.org/10.1007/s12403-013-0106-2 (2014).

19. Sengupta, D. \& Agrahari, S. Heavy Metal and Radionuclide Contaminant Migration in the Vicinity of Thermal Power Plants: Monitoring, Remediation, and Utilization (Springer, 2017). https://doi.org/10.1007/978-981-10-2410-8_2.

20. Proshad, R., Kormoker, T. \& Islam, S. Distribution, source identification, ecological and health risks of heavy metals in surface sediments of the Rupsa River, Bangladesh. Toxin Rev. https://doi.org/10.1080/15569543.2018.1564143 (2019).

21. Nadim, F., Hoag, G. E., Liu, S., Carley, R. J. \& Zack, P. Detection and remediation of soil and aquifer systems contaminated with petroleum products: An overview. J. Petrol. Sci. Eng. 26(1), 169-178. https://doi.org/10.1016/S0920-4105(00)00031-0 (2000).

22. Wang, C., Wang, W., He, S., Du, J. \& Sun, Z. Sources and distribution of alipHatic and polycyclic aromatic hydrocarbons in yellow river delta nature reserve China. Appl. Geochem. 26(8), 1330-1336. https://doi.org/10.1016/j.apgeochem.2011.05.006 (2011).

23. Hiller, K., \& Elahi, M. Structural development and hydrocarbon entrapment in the Surma Basin, Bangladesh (northeast Indoburman fold belt). In Porceedings pf the 5th Offshore South East Asia Conference, Seapex session, Singapore (1984).

24. Khan, M. M., Ismail, M., \& Ahmed, M. Geology and hydrocarbon prospect of the Surma basin, Bangladesh. In Proceedings pf the 7th Offshore South East Asia Conference, Seapex session, 2-5 February, Singapore (1988).

25. Faruque, M. O. Suitability assessment of groundwater around Tangratilla gas blowout affected area, NE Bangladesh. Asian Trans. Eng. 2(04), 1-11 (2012).

26. Khan, M. A. I. \& Nasir, F. B. A review over major gas blowouts In Bangladesh, their effects and the measures to prevent them in future. Int. J. Sci. Technol. Res. 3(9), 109-113 (2014).

27. Howladar, M. F. \& Rahman, M. M. Characterization of underground tunnel water hydrochemical system and uses through multivariate statistical methods: A case study from Maddhapara Granite Mine, Dinajpur, Bangladesh. Environ. Earth Sci. 75, 1501. https://doi.org/10.1007/s12665-016-6309-7 (2016).

28. Mamun, M. A. A., Howladar, M. F. \& Sohail, M. A. Assessment of surface water quality using fuzzy analytic hierarchy process (FAHP): A case study of Piyain River's sand and gravel quarry mining area in Jaflong, Sylhet, 9. Groundw. Sustain. Dev. https:// doi.org/10.1016/j.gsd.2019.03.002 (2019).

29. Numanbakth, M. A. A., Howladar, M. F., Faruque, M. O. \& Rahman, M. M. Understanding the hydrogeochemical characteristics of natural water for irrigation use around the hard rock mine in Maddhapara, Northwest Bangladesh. Groundw. Sustain. Dev. 8, 1. https://doi.org/10.1016/j.gsd.2019.02.007 (2019).

30. Rahman, M. M., Howladar, M. F., Hossain, M. A., Mazumder, A. T. M. S. H. \& Numanbakth, A. A. Impact assessment of anthropogenic activities on water environment of Tillai River and its surroundings, Barapukuria Thermal Power Plant, Dinajpur, Bangladesh. Groundw. Sustain. Dev. 10, 100310. https://doi.org/10.1016/j.gsd.2019.100310 (2020).

31. Banglapedia (2021). https://en.banglapedia.org/index.php/Sylhet_District (Accessed: 4 July 2021)

32. Almquist, Y. B., Ashir, S., \& Brännström, L., A Guide to Quantitative Methods, Version 1.0.1. (Stockholm University, Sweden, 2017). http://www.chess.su.se/polopoly_fs/1.173484.1396595707!/menu/standard/file/Almquist_Ashir_Brannstroem_Guide_1.0.1.pdf.

33. Reyment, R. A. \& Joreskog, K. G. Applied Factor Analysis in the Natural Sciences (Cambridge University Press, 1996).

34. Local Government Engineering Department (LGED) of Bangladesh 2020, date 30 June 2020.

35. Akoteyon, I. S., Omotayo, A. O., Soladoye, O. \& Olaoye, H. O. Determination of water quality index and suitability of urban river for municipal water supply in Lagos-Nigeria. Eur. J. Sci. Res. 54(2), 263-271 (2011).

36. Shen, F. et al. Contamination Evaluation and Source Identification of Toxic Metals in the Sediments from the Lishui River Watershed, Southern China (Environmental Research and Public Health, 2019).

37. WHO. Guidelines for Drinking-Water Quality (4th ed) (2011). http://www.whqlibdoc.who.int/publications/2011/9789241548151_ eng.pdf.

38. Hakanson, L. An ecological risk index for aquatic pollution control: A sediment ecological approach. Water Res. 14, 975-1001 (1980).

39. Tomlinson, D., Wilson, J., Haris, C. \& Jeffrey, D. Problems in the assessment of toxic-metal levels in estuaries and the formation of a pollution index. HelgoländerMeeresuntersuchungen 33, 566-575 (1980).

40. Yan, N. et al. Distribution and assessment of toxic metals in the surface sediment of Yellow River, China. J. Environ. Sci. China 39, 45-51 (2016).

41. Nemerow, N. L. Stream, Lake, Estuary, and Ocean Pollution (Van Nostrand Reinhold, 1991).

42. Soliman, N. F., Nasr, S. M. \& Okbah, M. A. Potential ecological risk of toxic metals in sediments from the Mediterranean coast, Egypt. J. Environ. Health Sci. Eng. 13, 70. https://doi.org/10.1186/s40201-015-0223-x (2015).

43. Xu, Z. Q., Ni, S. J. \& Tuo, X. G. Calculation of toxic metals toxicity coefficient in the evaluation of potential ecological risk index. Environ. Sci. Technol. 31, 112-115 (2008).

44. Mohammadi, A. A. et al. Carcinogenic and Noncarcinogenic Health Risk Assessment of Toxic Metals in Drinking Water of Khorramabad, Iran 1642-1651 (Elsivier, 2019).

45. Tay, C., Dorleku, M. \& Doamekpor, L. K. Human exposure risks assessment of toxic metals in groundwater within the Amansie and Adansi Districts in Ghana using pollution evaluation indices. West Afr. J. Appl. Ecol. 27(1), 23-41 (2019).

46. Rahman, M. A., Paul, M. \& Bhoumik, N. Heavy metal pollution assessment in the groundwater of the Meghna Ghat industrial area Bangladesh by using water pollution indices approach. Appl. Water Sci. 10, 186. https://doi.org/10.1007/s13201-020-01266-4 (2020).

47. Mohmand, J. et al. Human exposure to toxic metals via contaminated dust: Bio-accumulation trends and their potential risk estimation. Chemosphere 132, 142-151 (2015).

48. Chen, Y. et al. Arsenic exposure at low-to-moderate levels and skin lesions, arsenic metabolism, neurological functions, and biomarkers for respiratory and cardiovascular diseases: Review of recent findings from the Health effects of arsenic longitudinal study (HEALS) in Bangladesh. Toxicol. Appl. PHarmacol 239, 184-192 (2009).

49. Li, P., Qian, H., Howard, K. W. F. \& Wu, J. Toxic metal contamination of Yellow River alluvial sediments, northwest China. Environ. Earth Sci. 73(7), 3403-3415. https://doi.org/10.1007/s12665-014-3628-4 (2015).

50. Alam, R., Ahmed, Z. \& Howladar, M. F. Evaluation of heavy metal contamination in water, soil and plant around the open landfill site Mogla Bazar in Sylhet, Bangladesh. Groundw. Sustain. Dev. 10, 100311 (2020).

51. MacMillan, A., Preston, D., Wolfe, J., \& Yu, S. Basic statistics: Mean, median, average, standard deviation, z-scores, and p-value (2007). Retrieved from: https://controls.engin.umich.edu/wiki/index.pHp/Basic_statistics:_mean,_median,_average,_standard_ deviation,_zscores,_and_p-value.

52. Liu, C. W., Lin, K. H. \& Kuo, Y. M. Application of factor analysis in the assessment of groundwater quality in a blackfoot disease area in Taiwan. Sci. Total Environ. 313, 77-89. https://doi.org/10.1016/S0048-9697(02)00683-6 (2003).

53. US Environment Protection Agency. Guidelines for the Health Risk Assessment of Chemical Mixtures. Fed. Regist. 51, 34014-34025 (1986).

54. Xu, T., Wang, X., Li, T. \& Zhan, X. Heavy metal pollution of oil-based drill cuttings at a shale gas drilling field in Chongqing, China: A human health risk assessment for the workers. Ecotoxicol. Environ. Saf. 165, 160-163 (2018).

55. Guan, Y., Shao, C. \& Ju, M. Heavy metal contamination assessment and partition for industrial and mining gathering areas. Int. J. Environ. Res. Public Health 11(7), 7286-7303 (2014). 


\section{Acknowledgements}

Authors would like to thank to the Research Centre of Shahjalal University of Science Technology, Sylhet for funding (Grant Code: AS/2018/2/33) to accomplish this research. We also thankful to Soil Research Development Institutes (SRDI), Sylhet.

\section{Authors Contributions}

M.F.H. and N.H. conducted the measurements, data analysis and wrote the manuscript. K.A.A. performed laboratory analysis and a part of revision for this research. D.D. drew the ArcGIS Figures. These authors reviewed the manuscript before the final submission.

\section{Competing interests}

The authors declare no competing interests.

\section{Additional information}

Supplementary Information The online version contains supplementary material available at https://doi.org/ 10.1038/s41598-021-94830-0.

Correspondence and requests for materials should be addressed to M.F.H.

Reprints and permissions information is available at www.nature.com/reprints.

Publisher's note Springer Nature remains neutral with regard to jurisdictional claims in published maps and institutional affiliations.

(c) (i) Open Access This article is licensed under a Creative Commons Attribution 4.0 International License, which permits use, sharing, adaptation, distribution and reproduction in any medium or format, as long as you give appropriate credit to the original author(s) and the source, provide a link to the Creative Commons licence, and indicate if changes were made. The images or other third party material in this article are included in the article's Creative Commons licence, unless indicated otherwise in a credit line to the material. If material is not included in the article's Creative Commons licence and your intended use is not permitted by statutory regulation or exceeds the permitted use, you will need to obtain permission directly from the copyright holder. To view a copy of this licence, visit http://creativecommons.org/licenses/by/4.0/.

(C) The Author(s) 2021 